\title{
Ações dos gestores da comunicação empresarial: erros e acertos
}

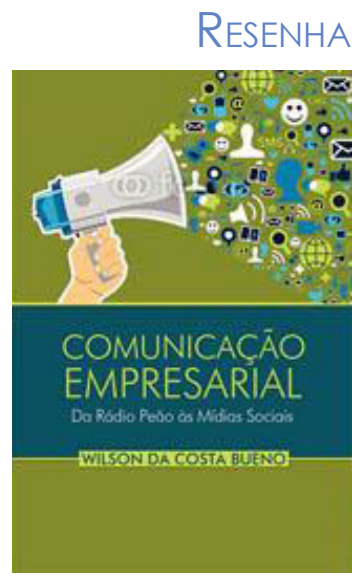

L João de Deus Dias Neto

Mestrando em Comunicação pela Universidade Municipal de São Caetano do Sul. Pós-graduado em Propaganda pela ESPM-SP (1989). Graduado em Administração pela Faculdade de Ciências Administrativas e Contábeis Paulo Eiró (1981). Professor da Universidade Anhanguera - Unidade Anchieta SBC-SP e do SENAC - Santo André-SP.

E-mail: deus.neto@uol.com.br

Wilson Bueno, não se abstendo de seu olhar crítico, de sua tradicional, ácida e provocante forma de identificar empresas desalinhadas com as boas práticas da comunicação empresarial, dá autenticidade, legitimação, ao desenvolver sua obra.

O prefácio, intitulado “O rei continua nu”, de autoria de Jorge Duarte, ex-aluno do autor, já expõe a realidade da comunicação organizacional no Brasil. Discute a situação de jovens recém-formados, com perspectivas de trabalharem em jornais, revistas, TV ou rádio, e que acabam assumindo funções na comunicação organizacional sem uma orientação adequada para desenvolvimento dos processos comunicacionais, tampouco quanto aos objetivos desta comunicação especializada.

Complementando este prefácio, o próprio autor apresenta o livro como "A comunicação empresarial sem maquiagem", ressaltando que a comunicação empresarial é importante demais para ser utilizada como instrumento de manipulação, sendo fundamental incorporar a essa área uma perspectiva crítica, comprometida com o diálogo, transparência e ética nos negócios. Desta forma, inicia seus escritos dividindo-os em cinco partes. Em todas faz uma exposição de bibliografia indicada; apresenta um rico material adicional, com textos e vídeos disponíveis na web, bem como insere questões pontuais para debates, tanto em ambientes universitários, quanto em ambientes de trabalho, o que ratifica a obra como instrumento muito adequado às discussões e busca de soluções para problemas e projetos de comunicação empresarial. 
A primeira parte do livro - "Os conceitos e práticas estão de cabeça para baixo" discute, através de doze textos, cenários e reflexões pertinentes a processos que envolvem a comunicação adequada aos diferentes tipos de stakeholders: comunicação com jovens e idosos, questões sobre a gestão da imagem corporativa, gestão de crise, questões de gênero e raça, subserviência sem vez e sem voz dos excluídos da comunicação, gestão do conhecimento disseminada a todos os envolvidos com a comunicação empresarial; aborda também a comunicação do autoelogio sem ouvir públicos de interesse, ausência de políticas sérias de comunicação, resistência das chefias, falta de competência, coragem e vontade política, por parte dos gestores, problemas na gestão de crises lastreadas na questão cultural especialmente em casos de recall, uso de maquiagem na comunicação e falta de transparência. Chega até o setor público e descortina casos em que a comunicação é cada vez menos pública e mais privatizada, situações de organizações que mantém-se na pré-história da comunicação, insegurança dos gestores "medo da própria sombra", aprofunda a análise sobre gestão de crises independentemente de onde elas acontecem. Ressalta a necessidade de um novo perfil dos comunicadores.

A segunda parte do livro, intitulada "A Comunicação com os públicos internos", disserta e provoca reflexões sobre ausência de líderes nos departamentos de comunicação, onde chefes estão mais presentes do que pessoas que sejam verdadeiros líderes em suas funções; discute também o assédio moral nas empresas, abre um fórum para questionar a existência de peleguismo na comunicação empresarial, evoca o problema do pluralismo no ambiente da comunicação interna da mesma forma que critica o autoritarismo nestes ambientes; analisa situações e cenários em que vestir a camisa da empresa é discutível; identifica como verificar a existência ou não de uma cultura de comunicação; aponta um neologismo: a Rádio Patrão; a vigilância na comunicação interna; instiga uma "virada de mesa" nos jornais empresariais, demonstra como é relevante ouvir colaboradores, alerta que "pensar em funcionários como protagonistas é estratégico", algo viável quando se elege como patrimônio principal das empresas, as pessoas. Finaliza esta parte evidenciando uma necessidade: desenvolvimento de intranets menos "entediantes".

$\mathrm{Na}$ terceira parte do livro, denominada "Conversando com a imprensa e com os Jornalistas", critica as relações empresariais com a imprensa. Em seus dez textos, comenta, discute e incita pensamentos e reflexões sobre a confiança necessária entre empresas e jornais, aborda fantasmas da mídia que assustam empresas; amplia os olhares que se limitam a dar relevância sobre analisar leads e releases; adentra a um espaço importante sobre questões de mídias regionais e processos de cidadania, bem como segmentação de mídia como solução da falta de dinamicidade das assessorias de imprensa. Neste capítulo também reforça as celeumas pertinentes a "monofontes" e lobbies. Apresenta a assessoria 
de imprensa sob uma ótica mais crítica e, na sequência, evidencia o desenvolvimento de competências das fontes através de media training. Encerra essa parte do livro discutindo notícias frias, publicadas com atraso, e a necessidade de inteligência no trato com a mídia.

Ao escrever a quarta parte do livro, chamada "Praticando a governança e a Sustentabilidade", o professor Wilson Bueno, em seis textos, fala sobre a sustentabilidade da comunicação como estratégia que revigora e reforça a imagem institucional. Nesse tópico, indica caminhos para ativismo, governança e situações de crime ambiental. Escreve, de forma lúcida e bem dirigida, exemplos que caracterizam hipocrisia empresarial na gestão de crises; estimula a necessidade de transparência nas questões de relacionamento com a mídia e governança corporativa. Adensa a discussão sobre agências, que esquecem a ética e escorregam nas questões de lobby. Como não poderia deixar de ser, traz à tona empresas que apresentam "discursos verdes" incongruentes com suas verdadeiras práticas operacionais.

Na quinta e última parte do livro, "Convivendo com o burburinho das redes sociais", Wilson da Costa Bueno amplia um alerta extremamente relevante aos gestores da comunicação empresarial sobre uma nova etapa no processo de comunicação e marketing das organizações: "As mídias sociais requerem revisão das práticas e posturas". Afirma que culturas organizacionais, avessas ao diálogo e à interação, não têm conseguido conviver harmoniosamente com este novo cenário e enfiam os pés pelas mãos porque desconhecem as regras do jogo.

Fecha seu livro, com cinco textos que abordam este assunto. Mostra com celeridade os processos baseados nas novas mídias e apresenta como estas tecnologias exigem um novo olhar dos gestores de comunicação. Discute o Twitter como ameaça ao autoritarismo na comunicação e o poder dessa ferramenta na comunicação interna. Faz uma premonição sobre o uso da "Rádio Twitter Peão", que poderá abalar empresas que não praticam comunicação interna democrática.

A obra, pela riqueza de abordagens e diversidade de exemplos, deve tornar-se referencial qualitativo a ser disseminado não apenas nos conteúdos dos cursos de Comunicação Social, mas também relacionado às práticas contemporâneas nos ambientes organizacionais.

BUENO, Wilson da Costa. Comunicação empresarial: do rádio peão às mídias sociais. São Bernardo do Campo: Editora Metodista, 2014. 239 p. 